\title{
Evaluation of In vivo Toxicity of Methanolic Leaf Extract of Vernonia lasiopus (O. Hoffman)
}

Michael N Musila ${ }^{1 *}$, Beatrice G Muthoni1 ${ }^{1}$, Samson C Koech ${ }^{1}$, Mathew P Ngugi ${ }^{1}$, Wilton M Mbinda ${ }^{2}$

${ }^{1}$ Department of Biochemistry and Biotechnology, Kenyatta University, Nairobi, Kenya

${ }^{2}$ Department of Physical Sciences, School of Pure and Applied Sciences, Karatina University, Kenya

"Corresponding author: Michael Ndile Musila, Department of Biochemistry and Biotechnology, Kenyatta University, Nairobi, Kenya, Tel: +254725270341; E-mail: 2mmusila@gmail.com

Received date: January 13, 2017; Accepted date: February 02, 2017; Published date: February 09, 2017

Copyright: (c) 2017 Musila MN, et al. This is an open-access article distributed under the terms of the Creative Commons Attribution License, which permits unrestricted use, distribution, and reproduction in any medium, provided the original author and source are credited.

\begin{abstract}
The main objective of this study was to evaluate the in vivo toxicity of methanolic leaf extract of Vernonia lasiopus. To provide information on the safety of $V$. lasiopus, we evaluated its acute and sub-chronic toxicity in Wistar rats. For evaluation of acute toxicity of the plant extract, five Wistar rats were orally dosed with $2000 \mathrm{mg} / \mathrm{kg}$ body weight sequentially. Sub-chronic toxicity was tested in twenty Wistar rats using three extract doses 100, 300 and $1000 \mathrm{mg} / \mathrm{kg}$ body weight. They were orally administered for 28 days. Mortality and toxicity signs were monitored during the study period. At the end of the experiment, the animals were sacrificed, their internal organs weighed and blood samples collected for haematology and biochemical analysis. In acute toxicity, no single death was reported; leading to conclusion that the median lethal dose (LD50) of methanolic leaf extract of $V$. lasiopus is beyond 2000 $\mathrm{mg} / \mathrm{kg}$ body weight. In sub-chronic toxicity studies, V. lasiopus lowered total proteins in all the study groups significantly. Albumin was also lowered at extract dose of $1000 \mathrm{mg} / \mathrm{kg}$ body weight. In addition, it resulted to significant neutropenia, lymphocytosis and thrombocytosis in the group administered with dose extract of 1000 $\mathrm{mg} / \mathrm{kg}$ body weight $(P<0.05)$. It was therefore concluded that methanolic leaf extract of $V$. lasiopus is safe for use when administered at therapeutic doses. The plant extract may also be useful in the management of haematological disorders especially thrombocytopenia.
\end{abstract}

Keywords: Vernonia lasiopus; Toxicity; Wistar rats; In vivo; Methanolic leaf extract

\section{Introduction}

Medicinal plants have been helpful in treating both infectious and life style diseases. Knowledge on their use has been preserved by passing it through oral communication and cultural practices by communities around the world [1]. They also play a role in the development of conventional drugs in modern age. However, the main drawback in the use of ethnobotanical medicine is the fact that the dosage is non-standardized and most of the plants have not been evaluated for toxicity [2]

On the other hand, global upsurge in therapeutic application of medicinal plants has been accompanied by various toxicological effects including drug overdose, drug dependence, hypersensitivity and idiosyncratic reactions [3]. The observed adverse reactions have direct effects on various body organs especially the liver and the kidney which are more predisposed to toxic effects of xenobiotics during their metabolism and excretion [3].

A major cause of toxicity includes plant misidentification, use of medicinal plants of unknown toxicity and contamination of medicinal plants with nephrotoxic non-herbal drugs [4]. In addition, presence of traces of pesticides and heavy metals, consumption of meat from animal that has grazed on toxic plants and interaction of conventional drugs with herbal compounds, have a time resulted to toxic effects [4]. Consumption of toxic plants leads to bioaccumulation of toxic herbal compounds or altered detoxification processes [5].
Vernonia lasiopus (O. Hoffman) is a plant that grows to a maximum height of about $3 \mathrm{~m}$ and has smooth greyish brown bark. It has oval shaped and densely hairy leaves with pale mauve or white flowers in colour [6]. V. lasiopus belongs to the tribe of Vernonieae and the family Asteraceae with about 1500 described species [7]. Most of the Vernonia species are found in temperate, tropical and sub-tropical areas, especially in South America, Asia, Africa and North America [8]. V. lasiopus is widely distributed in bush land, grassland, woodland and forest. It grows in an altitude between 1000 to $2500 \mathrm{~m}$. In Ethiopia, Vernonia species are used to treat eye infections, wounds and bone related problems such as fractures [9]. In Kenya, V. lasiopus is used to treat malaria and helminthic infections by decoction of leaves and bark [10]. V. lasiopus has also been in use traditionally in treating fever, abdominal pain, diarrhoea, sores, venereal diseases, scabies and ascariasis among other ailments [11]. This plant has been shown to have pain relieve ability, sedating power, anti-ulcerogenic and membrane stabilizing activities on reduced red blood cells [12-13]. It also has erythropoiesis and leucopoiesis stimulating power [12-13]. Despite extensive traditional use and scientific evaluated properties of this plant, little has been done in investigating in vivo toxic effects of the plant. It is against this back ground that we designed this study with the objective of investigating acute and sub-chronic oral dose toxicity of methanolic leaf extract of V. lasiopus in Wistar rat models, as part of the safety evaluation. 
Page 2 of 6

\section{Materials and Methodology}

\section{Plant material collection}

Fresh leaves of Vernonia lasiopus plant were collected with the help of a local traditional herbalist in Embu County. The plant materials were transported to Biochemistry and Biotechnology laboratory at Kenyatta University, where they were shade dried for two weeks at room temperature. A voucher specimen was deposited at Kenyatta University Herbarium after botanical authentication by a taxonomist.

\section{Extraction}

Dried leaves of $V$. lasiopus were crashed into a fine powder using electric mill. To obtain an extract, $500 \mathrm{~g}$ of the fine powder was soaked in one litre of methanol for 24 hours. After filtration of the extract using Whatman filter paper No. 1, the filtrate was evaporated to dryness under reduced pressure using rotary evaporator at $40^{\circ} \mathrm{C}$.

\section{Experimental animals}

Male Wistar rats aged between 8-10 weeks were obtained from Kenyatta University Animal house, Department of Biochemistry and Biotechnology. The animals were randomly selected and caged in groups of five. They were kept at standard laboratory conditions of temperature $\left(25 \pm 2^{\circ} \mathrm{C}\right)$, relative humidity $(60 \pm 5 \%)$ and $12 / 12$-h light/ dark cycle. Commercial rodent feed was supplied as food and water provided ad libitum. Five days acclimatization was observed before beginning the experiments. Guidelines from Organization for Economic Cooperation and Development on animal studies were followed on handling the animals [14]. Research permit was obtained from National Commission of Science, Technology and Innovation. Permission from Ethics Committee of the Kenyatta University on research on animal models was also granted.

\section{Acute toxicity studies}

Up and down method was used to perform a limit test at dose extract of $2000 \mathrm{mg} / \mathrm{kg}$ body weight [15]. Baseline weight after overnight fasting of the rats was used to calculate individual dose for each animal. The test was carried out using 5 male Wistar rats. Extract dose of $2000 \mathrm{mg} / \mathrm{kg}$ body weight was sequentially administered to each animal at 48 hours interval by oral gavages. For the first four hours, the animals were denied access to food. Only water was provided ad libitum. Signs of toxicity and fatality were observed up to 14 days and the results recorded. Special attention was given to the first three hours after administration of the extract.

\section{Sub-chronic toxicity testing}

The animals were divided into four groups each containing five animals. Group 1 was the control. This group was orally administered with $0.5 \mathrm{ml}$ of $1 \%$ DMSO for 28 days. Groups 2, 3 and 4 were orally administered with methanolic leaf extract of $V$. lasiopus at extract dose of $(100,300$ and 1000$) \mathrm{mg} / \mathrm{kg}$ body weight respectively, daily for 28 days. A progression factor of 3.2 was used to arrive at the three doses [15]. The animals were fed on commercial rodent feed and water was provided ad libitum.

\section{Samples collection}

On the $29^{\text {th }}$ day, animals were anaesthetized in air tight dissection jar containing cotton soaked in chloroform and blood collected through cardiac puncture. Whole blood for full hemogram tests was collected in anticoagulated tubes containing Ethylediaminetetraacetic Acid (EDTA) anticoagulant and kept at $4^{\circ} \mathrm{C}$. Blood for Renal Function Tests (RFT) and Liver Function Tests (LFT) was collected in tubes without anticoagulant. After clotting, the blood was centrifuged at $3000 \mathrm{rpm}$ for five minutes to obtain serum which was kept at $-20^{\circ} \mathrm{C}$ awaiting analysis. The tests performed included blood Glucose, Alanine Aminotransferase (ALT), Aspartate Aminotrasferase (AST), total proteins, albumin, creatinine, urea and uric acid. The anesthetized animals were later laid on a dissection board and opened up by cutting through vertical mid-line from neck to peritoneum using a pair of scissors. Body organs (brain, heart, liver, kidneys and pancreas) were excised blotted and weighed using digital weighing balance. The organs were preserved in plastic containers containing $10 \%$ buffered saline.

\section{Statistical data analysis}

The data obtained was presented in tables and graphs. Values were expressed as mean \pm Standard Error of Mean (SEM). One-way analysis of variance (ANOVA) was used to analyze data obtained from each animal body and organs weight, haematological tests and biochemical tests. Minitab statistical computer software v.17 (Minitab Inc., Pennsylvania, USA) was used in analyzing the data. Tukey's Honest Significant Difference test was used to separate means at a confidence level of $95 \%(\mathrm{p} \leq 0.05)$.

\section{Qualitative phytochemical screening}

Qualitative phytochemical screening for the presence of phenolic compounds, terpenoids, saponins, sterols, cardiac glycosides, alkaloids and flavonoids was done using methods described by Kotake [16].

\section{Results}

\section{Acute toxicity}

Administration of $2000 \mathrm{mg} / \mathrm{kg}$ body weight of methanolic extracts of $V$. lasiopus resulted in decreased activity, wheeze, pilo-erection and anorexia in the Wistar rats. However, these symptoms lasted for less than three hours. The severity of these symptoms decreased with time.

\section{Sub-chronic toxicity}

Effects of methanolic leaf extract of Vernonia lasiopus on body and organ weight in Wistar rats: The results obtained following administration of methanolic leaf extract of $V$. lasiopus, clearly indicate that there was no significance difference in weight observed between the treatment groups and the control group. Only a gradual insignificant weekly gain in weight was observed in all the groups ( $p>0.05$; Figure 1). In addition, the differences in weight of organs (brain, liver, kidney, spleen, lungs and heart) of the treated animals was not statistically outstanding when compared to the control group ( $p>0.05$; Table 1). 
Citation: Michael N Musila, Beatrice G Muthoni, Samson C Koech, Mathew P Ngugi, Wilton M Mbinda (2017) Evaluation of In vivo Toxicity of Methanolic Leaf Extract of Vernonia lasiopus (O. Hoffman). J Pharmacogn Nat Prod 3: 133. doi:10.4172/2472-0992.1000133

Page 3 of 6

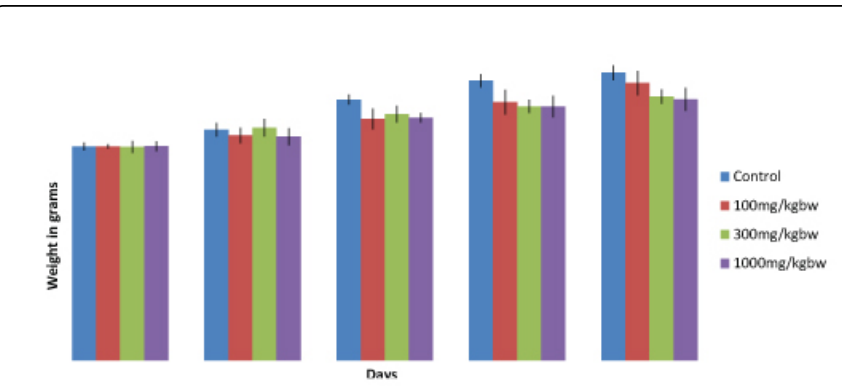

Figure 1: Effects of methanolic leaf extract of Vernonia lasiopus on body weight in Wistar rats.

\begin{tabular}{|l|l|l|l|l|}
\hline \multirow{2}{*}{ Organ } & \multicolumn{3}{l}{ Treatment groups } \\
\cline { 2 - 5 } & Control & $\mathbf{1 0 0} \mathbf{~} \mathbf{g} / \mathbf{k g b w}$ & $\mathbf{3 0 0} \mathbf{~} \mathbf{g} / \mathbf{k g b w}$ & $\mathbf{1 0 0 0} \mathbf{~ m g} / \mathbf{k g b w}$ \\
\hline Brain & $1.97 \pm 0.04^{\mathrm{a}}$ & $1.92 \pm 0.052^{\mathrm{a}}$ & $1.99 \pm 0.08^{\mathrm{a}}$ & $1.82 \pm 0.07^{\mathrm{a}}$ \\
\hline Liver & $11.35 \pm 1.20^{\mathrm{a}}$ & $11.63 \pm 0.92^{\mathrm{a}}$ & $8.27 \pm 0.56^{\mathrm{a}}$ & $9.56 \pm 0.20^{\mathrm{a}}$ \\
\hline Kidney & $1.72 \pm 0.15^{\mathrm{a}}$ & $1.79 \pm 0.08^{\mathrm{a}}$ & $1.47 \pm 0.5^{\mathrm{a}}$ & $1.52 \pm 0.27^{\mathrm{a}}$ \\
\hline Spleen & $1.01 \pm 0.09^{\mathrm{a}}$ & $0.90 \pm 0.21^{\mathrm{a}}$ & $0.79 \pm 0.09^{\mathrm{a}}$ & $0.87 \pm 0.07^{\mathrm{a}}$ \\
\hline Lungs & $2.93 \pm 0.17^{\mathrm{a}}$ & $2.67 \pm 0.19^{\mathrm{a}}$ & $2.59 \pm 0.27^{\mathrm{a}}$ & $2.36 \pm 0.15^{\mathrm{a}}$ \\
\hline Heart & $0.77 \pm 0.03^{\mathrm{a}}$ & $0.85 \pm 0.04^{\mathrm{a}}$ & $0.73 \pm 0.05^{\mathrm{a}}$ & $0.73 \pm 0.06^{\mathrm{a}}$ \\
\hline
\end{tabular}

Table 1: Effects of oral administration of methanolic leaf extract of Vernonia lasiopus on organ weight in Wistar rats.

\begin{tabular}{|c|c|c|c|c|}
\hline \multirow[b]{2}{*}{ Parameters } & \multicolumn{4}{|c|}{ Dose of Vernonia lasiopus ( $\mathrm{mg} / \mathrm{kbw} /$ day) } \\
\hline & Control & 100 & 300 & 1000 \\
\hline $\mathrm{GL}(\mathrm{mmol})$ & $6.76 \pm 1.10^{\mathrm{a}}$ & $\begin{array}{ll}6.38 & \pm \\
0.93^{\mathrm{a}} & \end{array}$ & $\begin{array}{ll}8.52 & \pm \\
0.86^{\mathrm{a}} & \end{array}$ & $\begin{array}{l}6.36 \\
0.67^{a}\end{array}$ \\
\hline PROT (g/l) & $68.98 \pm 2.32^{\mathrm{a}}$ & $\begin{array}{l}54.8 \\
1.76^{\mathrm{b}}\end{array}$ & $\begin{array}{l}54.44 \\
1.38^{\mathrm{b}}\end{array}$ & $\begin{array}{l}58.58 \\
3.39^{\mathrm{b}}\end{array}$ \\
\hline ALB (g/l) & $31.72 \pm 1.61^{a}$ & $\begin{array}{l}27.96 \\
1.18^{\mathrm{ab}}\end{array}$ & $\begin{array}{l}27.80 \\
1.74^{\mathrm{ab}}\end{array}$ & $\begin{array}{l}24.14 \\
1.84^{\mathrm{b}}\end{array}$ \\
\hline ALT (IU/L) & $\begin{array}{l}145.46 \\
3.59^{\mathrm{a}}\end{array}$ & $\begin{array}{l}159.06 \\
5.17^{\mathrm{a}}\end{array}$ & $\begin{array}{l}143.16 \\
2.68^{a}\end{array}$ & $\begin{array}{l}154.82 \\
4.31^{\mathrm{a}}\end{array}$ \\
\hline AST (IU/L) & $\begin{array}{l}189.44 \\
6.51^{\mathrm{a}}\end{array}$ & $\begin{array}{l}178.9 \\
8.04^{a}\end{array}$ & $\begin{array}{l}194.56 \quad \pm \\
4.25^{\mathrm{a}}\end{array}$ & $\begin{array}{l}164.04 \\
6.73^{\mathrm{a}}\end{array}$ \\
\hline AST/ALT & $1.74 \pm 0.24^{\mathrm{a}}$ & $\begin{array}{l}1.72 \\
0.12^{\mathrm{a}}\end{array}$ & $\begin{array}{l}1.95 \\
0.17^{a}\end{array}$ & $\begin{array}{l}1.97 \\
0.31^{\mathrm{a}}\end{array}$ \\
\hline D.BIL $(\mu \mathrm{m})$ & $0.44 \pm 0.21^{\mathrm{a}}$ & $\begin{array}{l}0.24 \\
0.19^{\mathrm{a}}\end{array}$ & $\begin{array}{l}0.56 \\
0.35^{a}\end{array}$ & \begin{tabular}{|l}
0.26 \\
$0.12^{\mathrm{a}}$
\end{tabular} \\
\hline T.BIL $(\mu \mathrm{m})$ & $3.55 \pm 0.57^{\mathrm{a}}$ & $\begin{array}{l}1.69 \\
0.88^{\mathrm{a}}\end{array}$ & $\begin{array}{l}3.32 \\
0.56^{a}\end{array}$ & $2.6 \pm 0.69^{a}$ \\
\hline CRE $(\mu \mathrm{m})$ & $47.90 \pm 5.64^{a}$ & $\begin{array}{l}45.96 \\
8.14^{\mathrm{a}}\end{array}$ & $\begin{array}{l}55.66 \\
4.26^{\mathrm{a}}\end{array}$ & $\begin{array}{l}62.04 \\
7.49^{a}\end{array}$ \\
\hline UREA (mmol) & $8.29 \pm 0.56^{a}$ & $\begin{array}{l}7.28 \\
0.41^{a}\end{array}$ & $\begin{array}{ll}8.68 & \pm \\
0.21^{\mathrm{a}} & \pm\end{array}$ & $\begin{array}{l}7.14 \\
0.46^{a}\end{array}$ \\
\hline $\mathrm{UA}(\mu \mathrm{m})$ & $\begin{array}{l}342.7 \\
49.10^{a}\end{array}$ & $\begin{array}{l}389.7 \\
44.20^{\mathrm{a}}\end{array}$ & $\begin{array}{l}384.9 \\
30.90^{\mathrm{a}}\end{array}$ & $\begin{array}{l}290.7 \\
42.40^{\mathrm{a}}\end{array}$ \\
\hline
\end{tabular}
did not show any significant difference in all the treatment groups when compared to the control group ( $p>0.05$; Table 3). Neutrophils decreased significantly in all the treatment groups when compared to the control group $(\mathrm{p}<0.05$; Table 3$)$. On the contrary, lymphocytes, platelets and platecrit were significantly raised after administration of extract dose of $1000 \mathrm{mg} / \mathrm{kg}$ body weight $(\mathrm{p}<0.05$; Table 3$)$.

\begin{tabular}{|l|l|l|l|l|}
\hline \multicolumn{5}{|l|}{ Dose of Vernonia lasiopus (mg/kgbw/day) } \\
\hline Parameters & Control & 100 & 300 & 1000 \\
\hline $\begin{array}{l}\text { RBC (1012/L) } \\
\text { Hb (g/dL) }\end{array}$ & $\begin{array}{l}6.44 \pm 0.18^{\mathrm{a}} \\
14.18 \pm 0.34^{\mathrm{a}}\end{array}$ & $\begin{array}{l}6.49 \pm 1.53^{\mathrm{a}} \\
15.18 \pm 0.61^{\mathrm{a}}\end{array}$ & $\begin{array}{l}6.59 \pm 0.26^{\mathrm{a}} \\
14.84 \pm 0.34^{\mathrm{a}}\end{array}$ & $\begin{array}{l}6.8 \pm 0.54^{\mathrm{a}} \\
14.72 \pm 0.52^{\mathrm{a}}\end{array}$ \\
\hline $\mathrm{PCV}(\%)$ & $41.02 \pm 1.32^{\mathrm{a}}$ & $47.30 \pm 2.96^{\mathrm{a}}$ & $41.58 \pm 1.97^{\mathrm{a}}$ & $44.14 \pm 2.68^{\mathrm{a}}$ \\
\hline $\mathrm{MCV}(\mathrm{fL})$ & $63.86 \pm 0.95^{\mathrm{a}}$ & $62.04 \pm 1.58^{\mathrm{a}}$ & $63.20 \pm 2.18^{\mathrm{a}}$ & $66.18 \pm 2.38^{\mathrm{a}}$ \\
\hline $\mathrm{MCH}(\mathrm{pg} / \mathrm{cell})$ & $22.00 \pm 0.35^{\mathrm{a}}$ & $20.10 \pm 1.19^{\mathrm{a}}$ & $22.60 \pm 1.09^{\mathrm{a}}$ & $22.20 \pm 1.65^{\mathrm{a}}$ \\
\hline $\mathrm{MCHC}(\mathrm{g} / \mathrm{dL})$ & $34.56 \pm 0.35^{\mathrm{a}}$ & $32.32 \pm 1.16^{\mathrm{a}}$ & $35.98 \pm 2.03^{\mathrm{a}}$ & $33.46 \pm 1.44^{\mathrm{a}}$ \\
\hline RDW (\%) & $16.72 \pm 0.55^{\mathrm{a}}$ & $17.60 \pm 0.40^{\mathrm{a}}$ & $19.76 \pm 0.40^{\mathrm{a}}$ & $19.36 \pm 0.58^{\mathrm{a}}$ \\
\hline WBC (109/L) & $9.18 \pm 2.22^{\mathrm{a}}$ & $9.38 \pm 0.86^{\mathrm{a}}$ & $10.40 \pm 1.55^{\mathrm{a}}$ & $9.66 \pm 0.28^{\mathrm{a}}$ \\
\hline $\begin{array}{l}\text { Neutrophils } \\
(\%)\end{array}$ & $32.40 \pm 4.71^{\mathrm{a}}$ & $15.62 \pm 0.81^{\mathrm{b}}$ & $20.20 \pm 1.20^{\mathrm{b}}$ & $13.88 \pm 2.24^{\mathrm{b}}$ \\
\hline
\end{tabular}

Effects of methanolic leaf extract of Vernonia lasiopus on Exical parameters in Wistar rats: Extract dose of $1000 \mathrm{mg} / \mathrm{kg}$ the control group $(\mathrm{p}<0.05$; Table 2$)$. On the other hand, dose of 100 and $300 \mathrm{mg} / \mathrm{kg}$ body weight did not result in any statistically remarkable difference between the treatment groups and the control group $(\mathrm{p}<0.05$; Table 2$)$. All the extract doses resulted in significan reter alanine aminotransferse, direct bilirubin, total bilirubin, urea, glucose, uric acid, sodium and potassium) were not significantly different from the control in all the three doses administered ( $p>0.05$; Table 2).

Extract of Vernonia lasiopus on lasiopus did not induce any statistically palpable effects on red blood cells indices (Red blood cells count, haemoglobin, packed cell volume, mean corpuscular haemoglobin, mean corpuscular haemoglobin centration and red blood cells distribution width) among the treatment groups when compared to the control group ( $\mathrm{p}>0.05$; Table $3)$.

\begin{tabular}{|c|c|c|c|c|}
\hline \multirow[b]{2}{*}{ Parameters } & \multicolumn{4}{|c|}{ Dose of Vernonia lasiopus (mg/kgbw/day) } \\
\hline & Control & 100 & 300 & 1000 \\
\hline RBC (1012/L) & $6.44 \pm 0.18^{\mathrm{a}}$ & $6.49 \pm 1.53^{\mathrm{a}}$ & $6.59 \pm 0.26^{a}$ & $6.8 \pm 0.54^{a}$ \\
\hline $\mathrm{Hb}(\mathrm{g} / \mathrm{dL})$ & $14.18 \pm 0.34^{a}$ & $15.18 \pm 0.61^{a}$ & $14.84 \pm 0.34^{a}$ & $14.72 \pm 0.52^{\mathrm{a}}$ \\
\hline PCV (\%) & $41.02 \pm 1.32^{\mathrm{a}}$ & $47.30 \pm 2.96^{a}$ & $41.58 \pm 1.97^{\mathrm{a}}$ & $44.14 \pm 2.68^{\mathrm{a}}$ \\
\hline $\mathrm{MCV}(\mathrm{fL})$ & $63.86 \pm 0.95^{\mathrm{a}}$ & $62.04 \pm 1.58^{\mathrm{a}}$ & $63.20 \pm 2.18^{\mathrm{a}}$ & $66.18 \pm 2.38^{\mathrm{a}}$ \\
\hline $\mathrm{MCH}(\mathrm{pg} / \mathrm{cell})$ & $22.00 \pm 0.35^{a}$ & $20.10 \pm 1.19^{a}$ & $22.60 \pm 1.09^{\mathrm{a}}$ & $22.20 \pm 1.65^{a}$ \\
\hline $\mathrm{MCHC}(\mathrm{g} / \mathrm{dL})$ & $34.56 \pm 0.35^{\mathrm{a}}$ & $32.32 \pm 1.16^{\mathrm{a}}$ & $35.98 \pm 2.03^{\mathrm{a}}$ & $33.46 \pm 1.44^{a}$ \\
\hline RDW (\%) & $16.72 \pm 0.55^{\mathrm{a}}$ & $17.60 \pm 0.40^{\mathrm{a}}$ & $19.76 \pm 0.40^{\mathrm{a}}$ & $19.36 \pm 0.58^{\mathrm{a}}$ \\
\hline WBC (109/L) & $9.18 \pm 2.22^{\mathrm{a}}$ & $9.38 \pm 0.86^{a}$ & $10.40 \pm 1.55^{\mathrm{a}}$ & $9.66 \pm 0.28^{a}$ \\
\hline $\begin{array}{l}\text { Neutrophils } \\
(\%)\end{array}$ & $32.40 \pm 4.71^{\mathrm{a}}$ & $15.62 \pm 0.81^{b}$ & $20.20 \pm 1.20^{b}$ & $13.88 \pm 2.24^{\mathrm{b}}$ \\
\hline
\end{tabular}




\begin{tabular}{|l|l|l|l|l|}
\hline $\begin{array}{l}\text { Lymphocyte } \\
(\%)\end{array}$ & $58.20 \pm 6.00^{\mathrm{b}}$ & $\begin{array}{l}71.18 \\
1.19^{\mathrm{ab}}\end{array}$ & $\begin{array}{l}67.60 \\
1.17^{\mathrm{ab}}\end{array}$ & $75.30 \pm 2.25^{\mathrm{a}}$ \\
\hline Monocytes (\%) & $8.0 \pm 1.41^{\mathrm{a}}$ & $12.20 \pm 1.39^{\mathrm{a}}$ & $10.80 \pm 0.97^{\mathrm{a}}$ & $9.02 \pm 2.21^{\mathrm{a}}$ \\
\hline $\begin{array}{l}\text { Eosinophils } \\
(\%)\end{array}$ & $1.00 \pm 0.55^{\mathrm{a}}$ & $0.80 \pm 0.58^{\mathrm{a}}$ & $0.60 \pm 0.25^{\mathrm{a}}$ & $0.40 \pm 0.40^{\mathrm{a}}$ \\
\hline Basophils (\%) & $0.20 \pm 0.20^{\mathrm{a}}$ & $0.20 \pm 0.20^{\mathrm{a}}$ & $0.40 \pm 0.25^{\mathrm{a}}$ & $0.60 \pm 0.25^{\mathrm{a}}$ \\
\hline $\begin{array}{l}\text { Platelets } \\
(109 / \mathrm{L})\end{array}$ & $361 \pm 47.9^{\mathrm{b}}$ & $523.8 \pm 41.5^{\mathrm{b}}$ & $529.8 \pm 48.1^{\mathrm{b}}$ & $733.2 \pm 28.1^{\mathrm{a}}$ \\
\hline PDW & $14.38 \pm 0.02^{\mathrm{a}}$ & $15.16 \pm 0.32^{\mathrm{a}}$ & $14.04 \pm 0.34^{\mathrm{a}}$ & $14.98 \pm 0.33^{\mathrm{a}}$ \\
\hline Platecrit\% & $0.27 \pm 0.04^{\mathrm{a}}$ & $0.37 \pm 0.03^{\mathrm{b}}$ & $0.36 \pm 0.05^{\mathrm{b}}$ & $0.89 \pm 0.15^{\mathrm{b}}$ \\
\hline
\end{tabular}

Values are expressed as Mean \pm SEM for five animals per group. Values with the same superscript across treatments are not significantly different from each other at $p>0.05$ (Analysed by ANOVA followed by Tukey's post hoc test). RBC: Red Blood Cells, Hb: Haemoglobin, PCV: Packed Cell Volume, MCV: Mean Cell Volume, MCH: Mean Corpuscular Haemoglobin, MCHC: Mean Corpuscular Haemoglobin Concentration, RDW: Red Blood Cells Distribution Width, WBC: White Blood Cells, PDW: Platelet Distribution Width.

Table 3: Effects of methanolic leaf extract of Vernonia lasiopus on haematological profiles in Wistar rats.

\section{Qualitative phytochemical screening}

Following standard phytochemical screening procedures, methanolic leaf extract of $V$. lasiopus was found to contain saponins, alkaloids, terpenoids, flavanoids and phenols. Cardiac glycosides and steroids were absent.

\section{Discussion}

The observed symptoms of toxicity which developed after acute exposure of $V$. lasiopus extract did not persist for long. In addition, there was no mortality reported in Wistar rats which received extract dose of $2000 \mathrm{mg} / \mathrm{kg}$ body weight of methanolic leaf extract of $V$. lasiopus. This suggests that the lethal dose (LD50) of methanolic leaf extract of $V$. lasiopus is beyond $2000 \mathrm{mg} / \mathrm{kg}$ body weight, hence safe for acute oral administration.

In sub-chronic testing, the significance decrease in albumin and total proteins is an indication that oral administration of methanolic leaf extract of $V$. lasiopus may have compromised synthetic function of the liver. Albumin synthesis is affected by hormonal balance, osmotic pressure and nutritional status. Low albumin is evident in liver cirrhosis and ascites. Albumin concentration is raised in cases of dehydration, increased corticosteroids and increased thyroid stimulating hormone [17]. Interfering with the liver cells alters liver synthetic function ultimately leading to decreased proteins and albumin synthesis [18].

Malnutrition can affect albumin and proteins synthesis [19] and this may explain the reason behind the observed low proteins and albumin. In addition, extract interference with nutrients absorption in the gut may lower the levels of albumin and proteins [20]. Study done by Muhammad et al. on acute and sub-chronic toxicity studies of kernel extract of Sclerocarya birrea in rats, gave similar results indicating that herbal extracts can inhibit protein synthesis [21].

Alanine Aminotransferase (ALT) is secreted by hepatocytes and is a specific marker of liver injury. Its level in blood rises following certain drug use or strenuous exercise [22]. Although this enzyme is mainly found in the liver, other organs including kidney, skeletal muscles and heart contain lesser amounts of the enzyme. The main function of this enzyme is transamination of amino acid alanine. Since ALT is mainly found in the cytosol, upon hepatocytes injury, the enzyme leaks into the extracellular space resulting in its rise in the plasma [23-24]. The insignificant rise in ALT indicates that there was no hepatic injury that occurred following administration of $V$. lasiopus. This is further supported by insignificant rise in AST, direct bilirubin and total bilirubin.

Aspartate Aminotrasferase is found both in the cytosol and mitochondrion and is widely distributed in many tissues compared to ALT [25]. Because of wide distribution of this enzyme in other tissues, it can be used to monitor other disorders in these tissues. However, in combination with ALT, it is a good maker of liver disease [24]. Bilirubin is classified as direct and indirect. Direct bilirubin is due to impaired hepatic secretion and obstruction to bile flow intra-hepatic or extra-hepatic. On the other hand, indirect bilirubin is mainly due to severe red blood cells haemolysis. Reduced uptake of bilirubin by hepatocytes, impaired conjugation, and reduced secretion can result in increase in both direct and indirect bilirubin [26-27].

In this study, both direct and indirect bilirubin rise was insignificant. We can therefore deduce from the study that $V$. lasiopus extract was safe to the liver at all the three doses administered orally, since it did not cause any significant rise in makers of liver toxicity.

The main function of the kidney is to excrete excess metabolic end products and to retain important substances by re-absorption or by retention, in order to maintain consistency in the extracellular fluid [28]. When this is not possible, such products accumulate in the plasma resulting to increased levels. Urea a product of protein catabolism is excreted mainly through the kidney [29]. Increase in plasma urea is associated with high protein intake, anabolic effects of some drugs (tetracyclines and glucocorticoids), kidney diseases, urinary tract blockage, congestive heart failure, trauma or serious illness. Plasma urea can increase when glomerular filtration rate is low [30]. On the other hand, low levels are seen in surgery, trauma, malnutrition, opioids use and in use of anabolic steroids [31]. As a measure of kidney function test, serum urea level was not affected by administration of methanolic leaf extract of $V$. lasiopus.

In addition, creatinine a marker of kidney function test was also not significantly affected by administration of the extract. Creatinine is usually not metabolized by the kidney, is not protein bound and is inert physiologically, therefore a good marker of filtration in the kidney. Serum creatinine increases in both acute and chronic kidney failure. However, at times the creatinine levels may be unrelated to kidney injury since creatinine can be influenced by muscle composition, function and activity, diet and health status [30]. Blood urea nitrogen-creatinine ratio is usually elevated in acute renal failure in pre-renal conditions [25].

Furthermore, kidney diseases are associated with rise in uric acid level in the blood [32]. Both the kidney and the gastrointestinal tract plays a role in the elimination of uric acid, where by the kidney excretes about two-third of this product [33]. Uric acid, a product of purine metabolism may increase in plasma due to inherited metabolic disorders, excess purine rich diet intake, alcohol intake, hypoxia, preeclampsia and altered Adenosine Triphosphate (ATP) metabolism. On the other hand, decreased excretion can result from kidney disease, lead poisoning, organic acids and salicylates leading to its rise in blood 
Page 5 of 6

[25]. Methanolic leaf extract of V. lasiopus did not alter uric acid levels significantly, meaning that the extract was safe to the kidney.

In diagnosis of renal disorders, measurement of electrolytes reflects kidney ability to excrete and reabsorb substances. Electrolytes are used to diagnose conditions related to acid-base balance, endocrine conditions and water balance among other conditions. Decrease in potassium excretion in the distal tubule, coincides with its increase in serum [30]. Measurement of both potassium and sodium level in the animals that received the extract did not reflect any toxicity.

Compared to the control group, haemoglobin level, haematocrit and the red blood cell count were insignificantly high in groups administered with $V$. lasiopus extract. This shows that the extract may be containing phytochemicals, which at high doses stimulate erythropoiesis. Moreover, the extract did not cause toxic effects on red blood cell indices.

Methanolic extract of $V$. lasiopus caused significant rise in platelets and plateletcrit. This is in consistence with study done by Muriithi et al., who found out that leaf extract from $V$. lasiopus improved erythrocytic parameter profiles significantly [13]. In a similar study, Carica papaya, Ipomea batatas, Alternanthera sessilis, and Euphorbia hirta were found to have the ability to stimulate platelet production [34]. This proves the ability of plant extracts in stimulating platelets production. Saponins, tannins, and alkaloids have been found to act on the bone marrow, thereby enhancing production of platelets and preventing their destruction in the circulation [35]. Since the main regulator of platelet production is thrombopoietin, significant increase in platelets in animals that received methanolic leaf extract of $V$. lasiopus at $1000 \mathrm{mg} / \mathrm{kg}$ body weight, is an indication that the extract may be either containing substances similar to thrombopoietin or it may be stimulating thrombopoietin production [36].

The red blood cells indices in animals that received $V$. lasiopus extract were not altered significantly in comparison to the control group. This signifies that the extract did not cause any toxic effect in erythrocytes. However, V. lasiopus extract at a dose of $1000 \mathrm{mg} / \mathrm{kg}$ body weight caused significant rise in lymphocytes and decrease of neutrophils.

The bone marrow plays a key role in production of neutrophils and two thirds of cells production is dedicated to production of monocytes and granulocytes [37]. Neutrophils production is regulated by interleukin (IL) 23, IL-17 and granulocyte colony stimulating factor. This axis of neutrophils production is down regulated by the liver $\mathrm{X}$ receptors (LXRs) [38]. Therefore, the plant extract could have resulted in increased expression of LXRs in the liver. Neutrophil death through extrinsic apoptosis is triggered by tumor necrotic factor alpha (TNF- $\alpha$ ) which proceeds through cleavage of procaspase- 8 [39]. Plants extracts have demonstrated the ability to induce production of TNF- $\alpha$ [40-41]. Therefore, this may be a possible mechanism through which the plant extract may have resulted to significant decrease in neutrophils count.

In addition, dendritic and macrophage cells are responsible for engulfing apoptotic neutrophils. When this happens, the phagocytes decrease production of IL-23 subsequently resulting in decrease in IL-17 [37]. Through this process, neutrophil production is down regulated.

Research on nine Chinese medicine herbal extracts did show the ability of plant extracts to stimulate lymphocytes production and proliferation [42]. Similarly, the significant increase of lymphocytes may have been stimulated by phytochemicals in plant extract given.
However, chronic inflammation from repeated cell injury following daily oral administration of the plant extract can also result to significant increase in lymphocytes [43]. Similar results were obtained by Antai et al. following oral administration of ethanolic extracts of Gonglonema latifolium in rats [44]. In the study, neutrophils were significantly reduced in a non-dose dependent manner and lymphocytes increased significantly.

In addition to antimicrobial activities of phenols, some phenolic compounds have activity on platelets and others have been linked to anti-inflammatory activity [45]. They therefore may have contributed to the observed changes in both white blood cells and platelets. On the other hand, saponins have been reported to have anti-inflammatory activities and ability to fortify the immune system [46].

\section{Conclusion}

The conclusion drawn from this study is that methanolic leaf extract of $V$. lasiopus is practically safe for both acute and sub-chronic use when administered orally. It is therefore recommended to evaluate other different routes of administration (peritoneal, subcutaneous, intradermal and intramuscular). This is to figure out more benefits as well as toxic effects of this plant.

\section{Study limitations}

The study did not focus on histopathology analysis of the tissues and quantitative phytochemical analyses of the plant extract due to time and cost implications.

\section{Acknowledgement}

We acknowledge the Department of Biochemistry and Biotechnology Kenyatta University and Kwale Hospital for allowing us to use their facilities in conducting this study.

\section{References}

1. Gurib-Fakim A (2006) Medicinal plants: traditions of yesterday and drugs of tomorrow. Mol Aspects Med 27: 1-93.

2. Nabukenya I, Rubaire-Akiiki C, Mugizi D, Kateregga J, Olila D, et al. (2014) Sub-acute Toxicity of Aqueous Extracts of Tephrosia vogelii, Vernonia amygdalina and Senna occidentalis in Rats. Nat Prod Chem Res 2:1-5

3. George P (2011) Concerns regarding the safety and toxicity of medicinal plants-An overview. J Appl Pharmaceut Sci 1: 40-44.

4. Roshni PR, Jyothylekshmi V, Reghu R, Vijayan M (2014) Renal disease with the use of herbal remedies. Int J Pharmaceut Chem Biol Sci 4: 367-371

5. Chen XW, Serag ES, Sneed KB, Zhou SF (2011). Herbal bioactivation, molecular targets and the toxicity relevance. Chemico-Biological Interactions 192: 161-176.

6. Dharani N, Rukunga G, Yenesew A, Mbora A, Mwaura L, et al. (2010) Common antimalarial trees and shrubs of East Africa. A Description of Species and a Guide to Cultivation and Conservation Through Use. The World Agroforestry Centre (ICRAF), Nairobi, Kenya, p: 67.

7. Da-Silva JB, Temponi VDS, Gasparetto CM, Fabri RL, Aragão DMDO, et al. (2013) Vernonia condensata Baker (Asteraceae): A promising source of antioxidants. Oxidative Medicine and Cellular Longevity 2013: 1-9.

8. Redonda-Martínez R, Villaseñor JL, Terrazas T (2012) Trichome diversity in the Vernonieae (Asteraceae) of Mexico: Vernonanthura and Vernonia (Vernoniinae). J Torrey Bot Soc 139: 235-247.

9. Kalayou S, Haileselassie M, Gebre-egziabher G, Tiku'e T, Sahle S, et al. (2012) In-vitro antimicrobial activity screening of some ethnoveterinary 
Citation: $\quad$ Michael N Musila, Beatrice G Muthoni, Samson C Koech, Mathew P Ngugi, Wilton M Mbinda (2017) Evaluation of In vivo Toxicity of

medicinal plants traditionally used against mastitis, wound and gastrointestinal tract complication in Tigray Region, Ethiopia. Asian Pac J Trop Biomed 2: 516-522.

10. Kareru PG, Kenji GM, Gachanja AN, Keriko JM, Mungai G (2007) Traditional medicines among the Embu and Mbeere people of Kenya. Afr J Tradit Complement Altern Med 4: 75-86.

11. Galiwango J (2009) Some Pharmacological Effects of the Leaf Extracts of Vernonia lasiopus and Maesa lanceolata: Plants Traditionally used to Treat Common Ailments in Humans in East Africa. Master's Thesis, Makerere University, Kampala, Uganda, p: 6.

12. Erasto P, Grierson DS, Afolayan AJ (2006) Bioactive sesquiterpene lactones from the leaves of Vernonia amygdalina. J Ethnopharmacol 106: $117-120$.

13. Muriithi NJ, Maina GS, Maina MB, Kiambi MJ, Kelvin JK, et al. (2015) Determination of Hematological Effects of Methanolic Leaf Extract of Vernonia lasiopus in Normal Mice. Pharm Anal Acta 5: 1-6.

14. OECD (2001) Acute Oral Toxicity-Up and Down Procedure. OECD Guidelines for Testing of Chemicals 425: 1-26.

15. Osano KO, Nyamai DW, Ogola PE, Ouko RO, Arika, et al. (2016) Evaluation of In vivo Toxicity of Dichloromethane: Methanolic Leaf Extracts of Prosopis juliffora in Female Wistar Albino Rats. J Drug Metab Toxicol 7: 1-11.

16. Kotake CK (2000) Practical pharmacognosy. Vallabh prakashan, New Delhi, India 4: 107-111.

17. Nicholson JP, Wolmarans MR, Park GR (2000) The role of albumin in critical illness. Br J Anaesth 85: 599-610.

18. Sharma OP (2011) Clinical biochemistry of hepatotoxicity. J Clinic Toxicol 4: 1-19.

19. Saunders J, Brian A, Wright M, Stroud M (2010) Malnutrition and nutrition support in patients with liver disease. Frontline Gastroenterol 1 105-111.

20. Kpomah ED, Arhoghro EM, Uwakwe AA (2012) Biochemical and histopathological changes in Wistar rats following chronic administration of Diherbal mixture of Zanthoxylum leprieurii and Piper guineense. J Nat Sci Res 2: 22-28.

21. Muhammad S, Hassan LG, Dangoggo SM, Hassan SW, Umar KJ, et al. (2011) Acute and subchronic toxicity studies of kernel extract of Sclerocarya birrea in rats. Sci World J 6: 11-14.

22. Hall P, Cash J (2012) What is the real function of the liver 'function' tests? Ulster Med J 81: 30-36.

23. Senior JR (2012) Alanine Aminotransferase: a clinical and regulatory tool for detecting liver injury-past, present, and future. Clinical Pharmacology and Therapeutics 92: 332-339.

24. Arika WM, Nyamai DW, Osano KO, Ngugi MP, Njagi ENM, et al. (2016) Biochemical markers of in vivo hepatotoxicity. J Clin Toxicol 6: 1-8.

25. Burtis CA, Ashwood ER, Bruns DE (2012) Tietz Fundamentals of Clinical Chemistry (6th edn.). Elsevier Health Sciences, Phillaephia, USA, pp: 363-368.

26. Fevery J (2008) Bilirubin in clinical practice: a review. Liver Int 28: 592-605.

27. Maisels MJ, McDonagh AF (2008) Phototherapy for neonatal jaundice. N Engl J Med 358: 920-928.
28. Vlahakos DV, Marathias KP, Agroyannis B, Madias NE (2003) Posttransplant erythrocytosis. Kidney Int 63: 1187-1194.

29. Mavri-Damelin D, Eaton S, Damelin LH, Rees M, Hodgson HJ, et al. (2007) Ornithine transcarbamylase and arginase I deficiency are responsible for diminished urea cycle function in the human hepatoblastoma cell line HepG2. Int J Biochem Cell Biol 39: 555-564.

30. Gowda S, Desai PB, Kulkarni SS, Hull VV, Math AA, et al. (2010) Markers of renal function tests. N Am J Med Sci 2: 170-173.

31. Sherman DS, Fish DN, Teitelbaum I (2003) Assessing renal function in cirrhotic patients: problems and pitfalls. Am J Kidney Dis. 41: 269-278.

32. Johnson RJ, Kang DH, Feig D, Kivlighn S, Kanellis J, et al. (2003) Is there a pathogenetic role for uric acid in hypertension and cardiovascular and renal disease. Hypertension 41: 1183-1190.

33. Albertoni GA, Borges FT, Schor N (2012) Uric Acid and Renal Function. INTECH Open Access Publisher. Rijeka, Croatia, pp: 58-66.

34. Arollado EC (2014) Platelet augmentation activity of selected Philippine plants. Int J Pharm Phytopharmacol 3: 121-123.

35. Patil S, Shetty S, Bhide R, Narayanan S (2013) Evaluation of platelet augmentation activity of Carica papaya leaf aqueous extract in rats. J Pharmacogn Phytochem 1: 57-60.

36. Patrick-Iwuanyanwu KC, Amadi U, Charles IA, Ayalogu EO (2012) Evaluation of acute and sub-chronic oral toxicity study of baker cleansers bitters a polyherbal drug on experimental rats. EXCLI J 11: 632-640.

37. Borregaard N (2010) Neutrophils, from marrow to microbes. Immunity 33: 657-670.

38. Kolaczkowska E, Kubes P (2013) Neutrophil recruitment and function in health and inflammation. Nat Rev Immunol 13: 159-175.

39. Fox S, Leitch AE, Duffin R, Haslett C, Rossi AG, et al. (2010) Neutrophil apoptosis: relevance to the innate immune response and inflammatory disease. J Innate Immun 2: 216-227.

40. Bodinet C, Lindequist U, Teuscher E, Freudenstein J (2002) Effect of an orally applied herbal immunomodulator on cytokine induction and antibody response in normal and immunosuppressed mice. Phytomedicine 9: 606-613.

41. Zhai Z, Liu Y, Wu L, Senchina DS, Wurtele ES, et al. (2007) Enhancement of innate and adaptive immune functions by multiple Echinacea species. J Med Food 10: 423-434.

42. Hasan NM, Al Sorkhy MK (2014) Herbs that promote cell proliferation. Int J Herbal Med 1: 18-21.

43. Ueha S, Shand FH, Matsushima K (2011) Cellular and molecular mechanisms of chronic inflammation-associated organ fibrosis. Front Immunol 3: 71-71.

44. Antai AB, Ofem OE, Ikpi DE, Ukafia S, Agiang EA, et al. (2009) Phytochemistry and some haematological changes following oral administration of ethanolic root extract of Gonglonema latifolium in rats. Niger J Physiol Sci 24: 79-83.

45. Bakkali F, Averbeck S, Averbeck D, Idaomar M (2008) Biological effects of essential oils-a review. Food Chem Toxicol 46: 446-475.

46. Hoffman F, Manning M (2002). Herbal Medicine and Botanical Medical Fads. Haworth Press, New York, USA, pp: 29-43. 